
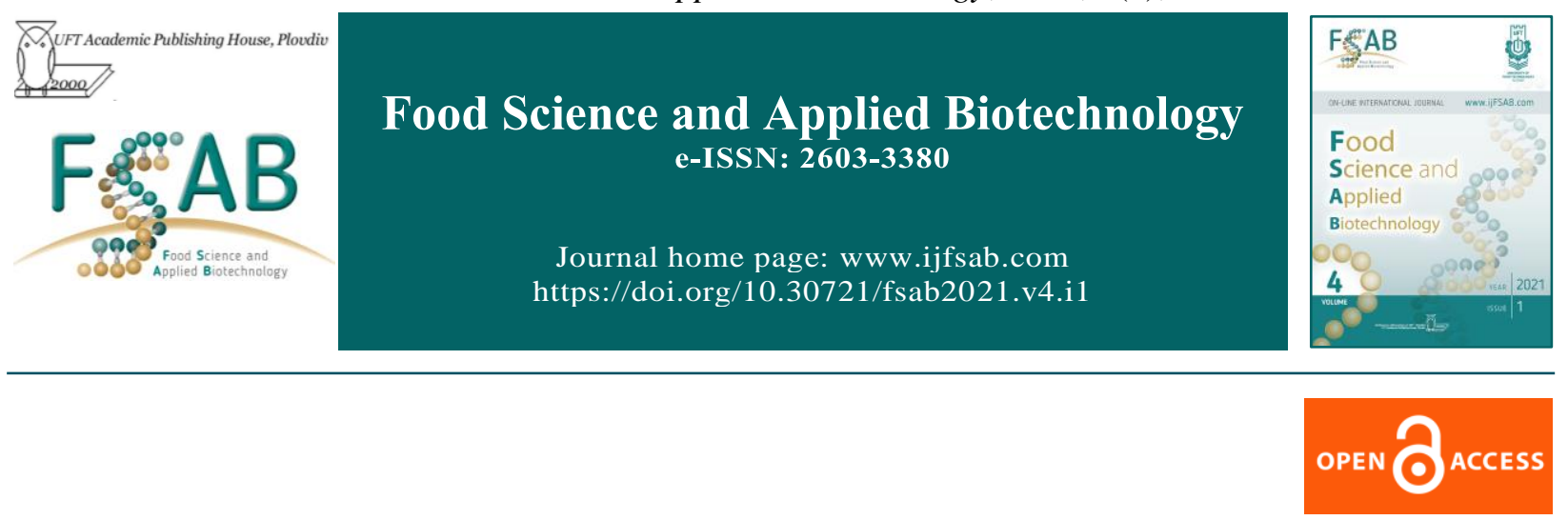

Research Article

\title{
Application of the descriptor-profile method in modeling the recipes of a preserved food using sprouted grain and malt extract
}

\author{
Marina Mikulinich $^{1 \square}$, Natalia Guzikova ${ }^{1}$ \\ ${ }^{1}$ Department of Merchandizing and Organization of Trade, Mogilev State University of Food Technologies, Mogilev, \\ Belarus
}

\begin{abstract}
The article reflects the possibilities of using the descriptor-profile method in modeling recipes of functional food products taking into account the consumer preferences. Preserved foods using sprouted bare-grained oats or wheat and barley-malt extract served as samples for research. The simulation of the consumer preferences of the preserved product was carried out using a descriptor-profile method of tasting analysis. There were thirty-two features of descriptors identified for assessing organoleptic indicators and emotional customers' perception of the product. A visual model of the consumer preferences of the preserved product was formed. The intensity and significance of each descriptor were determined. Influence of share of sprouted grain and malt extract on consumer preferences of preserved product was studied. Increasing the share of sprouted grain in the product reduced the coverage of the grain with the extract, the pallor and hardness of the grain, the intensity of brown color and the presence of malt-apple aroma. An "ideal" portrait of the product has been developed taking into account the strengths and weaknesses of the product, allowing to design organoleptic indicators at the stage of product development. High consumer preferences of the preserved product - a harmonious sweet taste with slight sourness, malt-apple-honey aroma, moderate grain hardness, lack of bitterness, - were achieved with $40 \%$ - 50\% sprouted grain and 50\% - 60\% extract.
\end{abstract}

Keywords: modeling, preserved product, sprouted grain, malt extract, ingredient composition, consumer preferences, descriptor, SWOT analysis, «ideal» portrait.

${ }^{\square}$ Corresponding author: Associate professor Marina Mikulinich, PhD, Department of Merchandizing and Organization of Trade in Technological Sciences, Mogilev State University of Food Technologies, 3, Shmidt Avenue, 212027, Mogilev, Belarus, mobile: +375 2917231 25; tel.: 80222635 409; E-mail: mikulinichmarina@gmail.com

\section{Article history:}

Received 05 September 2020

Reviewed 30 December 2020

Accepted 20 February 2021

Available on-line 19 March 2021

https://doi.org/10.30721/fsab2021.v4.i1.113

Mikulinich and Guzikova, 2021

(C) 2021 The Authors. UFT Academic publishing house, Plovdiv Modeling of preserved food recipes using descriptor-profile methods 


\section{Introduction}

The development and introduction into the production of functional food products from local raw materials, which would take into account the balance in the content of food and biologically active substances, is an actual area of research. A preserved product using sprouted grains and malt extracts is an optimal form of food that can be used to enrich the human diet with all the necessary nutrients that have a favorable effect on the metabolism and immune resistance of the body.

So, due to the presence of dietary fibers, fiber, a rich vitamin and mineral composition of sprouted grain (Berezhnaya et al. 2015; Samchenko and Merkucheva 2015), its use in the product will contribute to increase immunity, compensate for vitamin and mineral deficiency, normalize acidbase balance. Application in the technology of preserved production of malt or polymalt extract ("pouring") with a preserving effect (Pike et al. 2007; Burmagina and Gnezdilova 2015) and having a balance of easily digestible carbohydrates, amino acids, protein, vitamin and mineral substances (Znamenskaya 2009; Domaretsky 2011; Mikulinich et al. 2019), will have a prevention and treatment effect.

It should be noted that the preserved product using malt extracts and sprouted grains is a novelty product and there have been no studies on its production.

Analysis of literary sources (Chugunova and Zavorokhina 2010; Zavorokhina and Chugunova 2014; Safronova et al. 2017; Zabalueva et al. 2017; Pochitskaya et al. 2017; Prasol et al. 2017; Druker et al. 2018; Moiseeva and Motovilov 2019) showed that a descriptor-profile method of tasting analysis is used to solve various production and research problems, including the development of a new product with given properties. The importance was attached not only to the nutritional valye, but also to the emotional customers' perception of the product. Zavorokhina (2014) developed a methodology for modeling soft drinks, which allows to obtain products with given preferences taking into account the sensory preferences of consumers and using a descriptor-profile method. However, when designing any product, a certain approach is required taking into account the individual characteristics of the product.

The purpose of the work was to develop the technology of functional products using malt extracts, which make it possible to increase the efficiency of using lacal grain raw materials and provide the population with high-quality food products.

The scientific task was to develop an "ideal" portrait of the consumer preferences of the product using sprouted grain and malt extract to model recipes of preserved product with given properties.

\section{Materials and Methods}

Preserved foods using sprouted grain and malt extract were the objects of experimental research; the object of the study was the consumer preferences of the preserved product; the issue of the research was modeling organoleptic indices of the preserved product with specified properties.

Wheat grain of "Sudarynya" variety, bare-grained oats of "Gosha" variety, and "pouring" - barleymalt extract with a dry substance content of $72 \%$ were used as raw materials, produced by «Polotsk Drinks and Concentrates» factory, Republic of Belarus. Preparation of the grain for preservation included air-water soaking at a temperature of $14^{\circ} \mathrm{C}$ for $24-32 \mathrm{~h}$ until reaching a humidity of $45.0 \pm$ $0.5 \%$, pre-sprouting - at a temperature of $16-18^{\circ} \mathrm{C}$, for 2-3 days until reaching a sprout of $2 / 3$ of the grain length, blanching of the sprouted grain at a temperature of $85^{\circ} \mathrm{C}$ for $30 \mathrm{~min}$. The ratio of blanched sprouted grain (using bare-grained oats or wheat) and liquid barley-malt extract in the product were varied as follows (grain: extract): 33: 67, 40: 60, 50: 50, 60: 40, 67: $33 \%$. Mixing grain and extract was carried out at a temperature of $78^{\circ} \mathrm{C}$.

Preparation and conduct of tests were carried out according to the standards ISO 6564, ISO 8586, ISO 8587, ISO 11036 and ISO 13299. Consumer preferences of the preserved product were simulated by computer design in an Excel spreadsheet processor using a descriptor-profile method of tasting analysis. The calculation methodology was based on the principles proposed by Tragon (USA) Sidel and Stone (Stone and Sidel 2004; Stone 2005), Zavorokhina (Zavorokhina 2014; Zavorokhina and Chugunova 2014), sensory analysis (Bolotko and Mikulinich 2015), commodity examination (Evdokhova and Masansky 2013) and with regard to the development of scientific approaches to the creation of a preserved product using malt extracts 
developed for the first time.

The simulation scheme of the new preserved product using sprouted grain and malt extract is shown in Fig. 1.

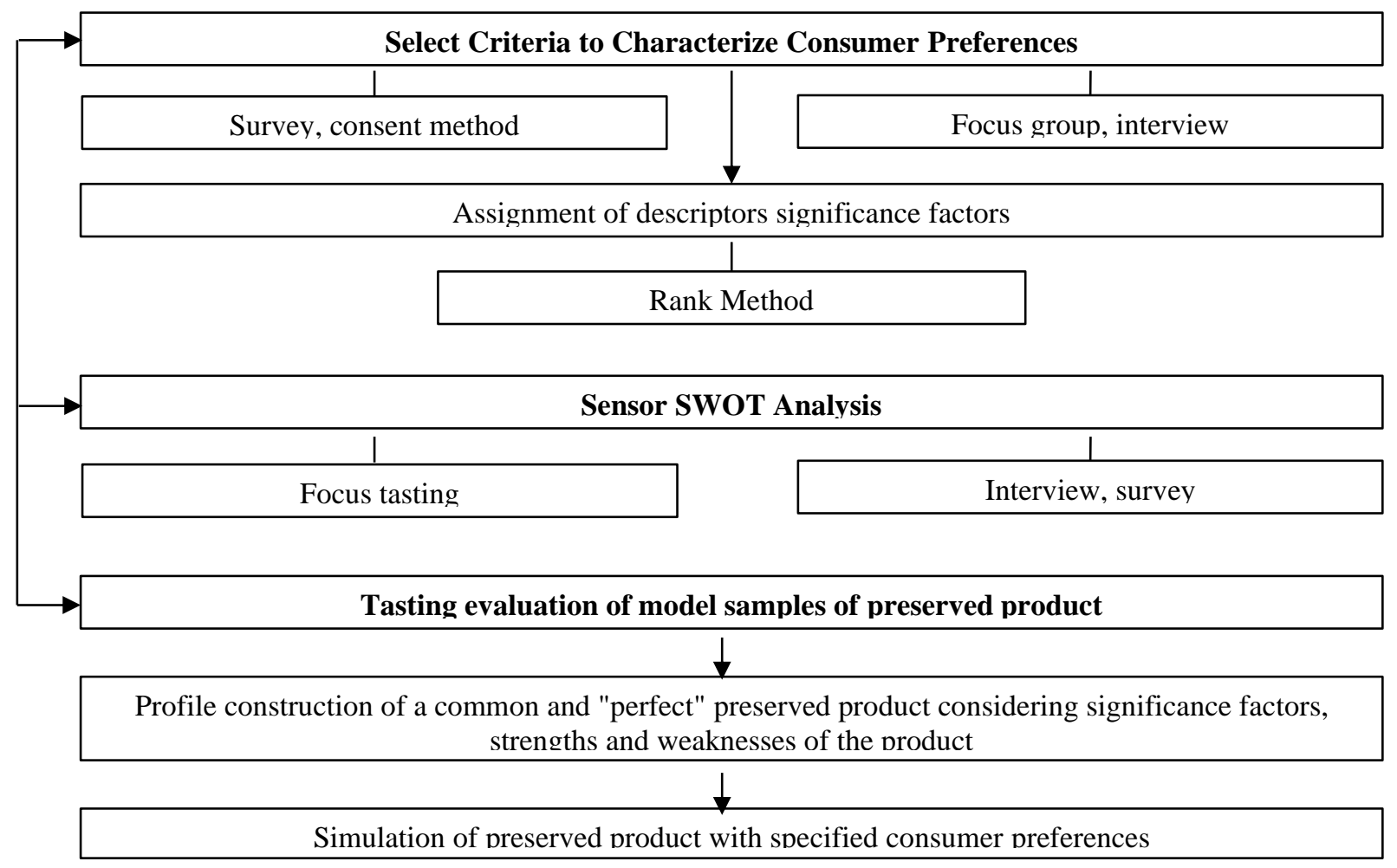

Figure 1. Algorithm of modeling of preserved product using the descriptor-profile method of tasting analysis

\section{Results and Discussion}

The descriptor panel includes significant descriptors of appearance, taste, aroma, texture, which reflect the sensory perception of the product as a whole (Zavorokhina and Chugunova 2014). The consent method was used to perform a descriptive analysis of the preserved product flavor. In the consent method, testers work as a group of testers to achieve an agreed description of the product flavor. The essential point in this method is that the team leader is also one of the experts.

The focus group included five trained testers who have experience in the field of commodity expertise, food technology, functional and specialized products.

During the in-depth interview with each tester, a conversation was held about the characteristics of the preserved product using malt extracts and sprouted grain with their focus on the organoleptic features of the food product, while taking into account the correct and objective interpretation of the concepts. So, the hedonic description of taste density, flavor, intensity, corresponds to such an objective description as saturation of taste; strong smell, fragrant, bright as the severity of the aroma. As a result, a group of testers identified 32 characteristics of descriptors (Fig. 2), descriptive characterizing the general profile of the preserved product: 11 characteristics for assessing appearance, 6 for assessing aroma, 10 for assessing taste, 3 for assessing consistency and 2 for evaluating emotional customers' perception of the product.

In the next step, the significance of the selected descriptors was determined by the rank method. The ranking procedure was that the most significant descriptor was assigned rank 1, and the least significant - the last. According to the survey the resulting ranks of ranking descriptors are defined as the rank sums for each descriptor. Significance coefficients of each of the ranking descriptors $b_{i \text { rank }}$ 
was calculated by the formula (provided that the sum of all significance coefficients $b_{i \text { rank }}$ from 1 to $n$ is equal to 1 ):

$$
\mathrm{b}_{\text {i ранг }}=\frac{\left(n-r_{n}+1\right)}{S_{n}}
$$

$\mathrm{n}$ - number of test descriptors within one indicator; $r_{n}$ - the resulting rank of the researched descriptor; $\mathrm{S}_{\mathrm{n}}$ - sum of the resulting ranks.

To convert the obtained values into integers, the significance coefficients were multiplied by 20 and rounded to an integer. The panel of descriptors with regard to significance coefficients is shown in Fig. 2.

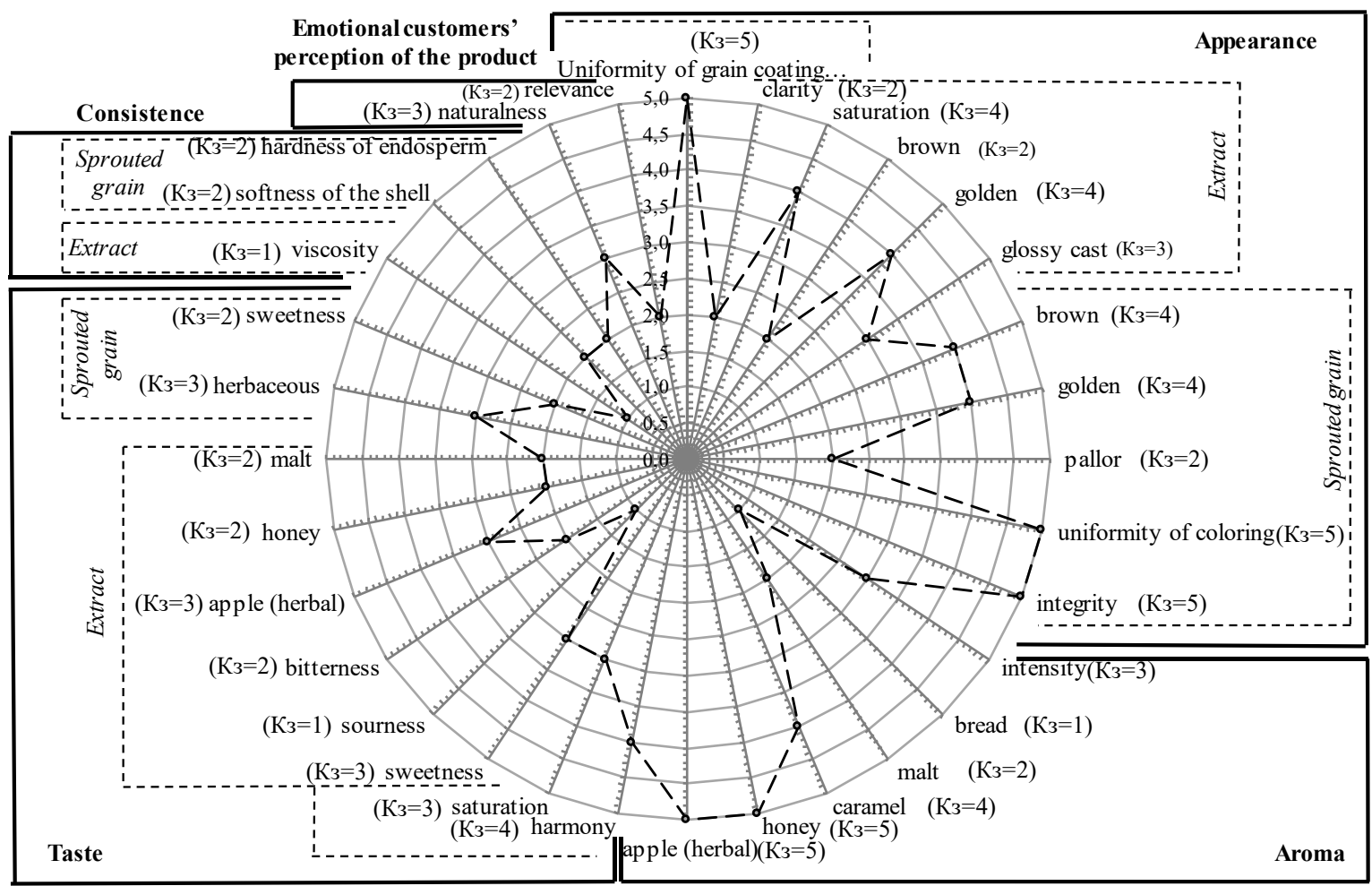

Figure 2. The panel of descriptors with the indication of coefficients of the importance $\left(\mathrm{K}_{3}\right)$

Analyzing the results presented in Fig. 2, it was noted that the most important descriptors in assessing the organoleptic characteristics of preserved products were the uniformity of the grain coating with extract, the saturation of golden color, uniformly colored golden brown color and whole grain, the severity of apple, honey and caramel aroma, the sweetness and saturation in taste of such "shades" as apple, honey and malt, harmonious taste. For the tasting of model samples of preserved products, the universal 5-point verbal scale is optimal: 0 - no sign, 1 - only recognizable or felt, 2 - weak intensity, 3 - moderate intensity, 4 - strong,
5 - very strong intensity (Bolotko and Mikulinich 2015), which is adapted to evaluate the preserved product using malt extract and sprouted grain (Fig. $3)$.

It should be noted that the "naturality" of the extract refers to how the tester or consumer perceives the product in chemical composition, for example, a subtle green cast may be perceived as not natural; "relevance" means how this product is perceived as by external signs, for example, as a separate product - replacing granola bars, or the ingredient replacing syrup in ice cream. 


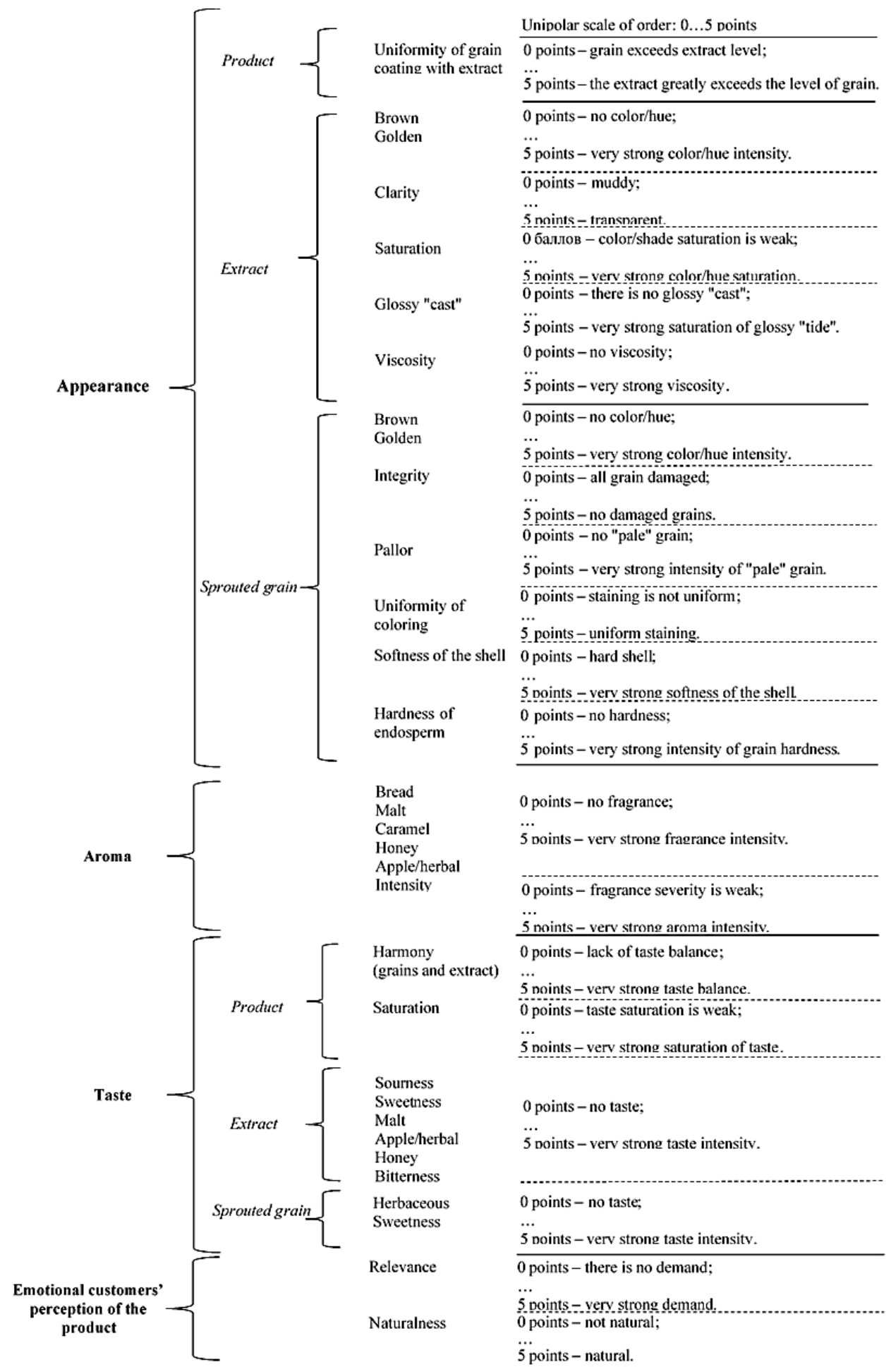

Figure 3. Model of consumer properties for preserved product using sprouted grain

The next step was to conduct a tasting assessment of model preserved products depending on the proportion of sprouted wheat grains or bare-grained oats and malt extract according to the developed panel of descriptors. The proportion of sprouted grain and malt extract ranged from 33 to $67 \%$ (grain: extract - 33:67, 40:60, 50:50, 60:40, 67:33). The received averaged scores were multiplied by significance factors and converted to a 5-point scale. The results are shown in Fig. 4. 

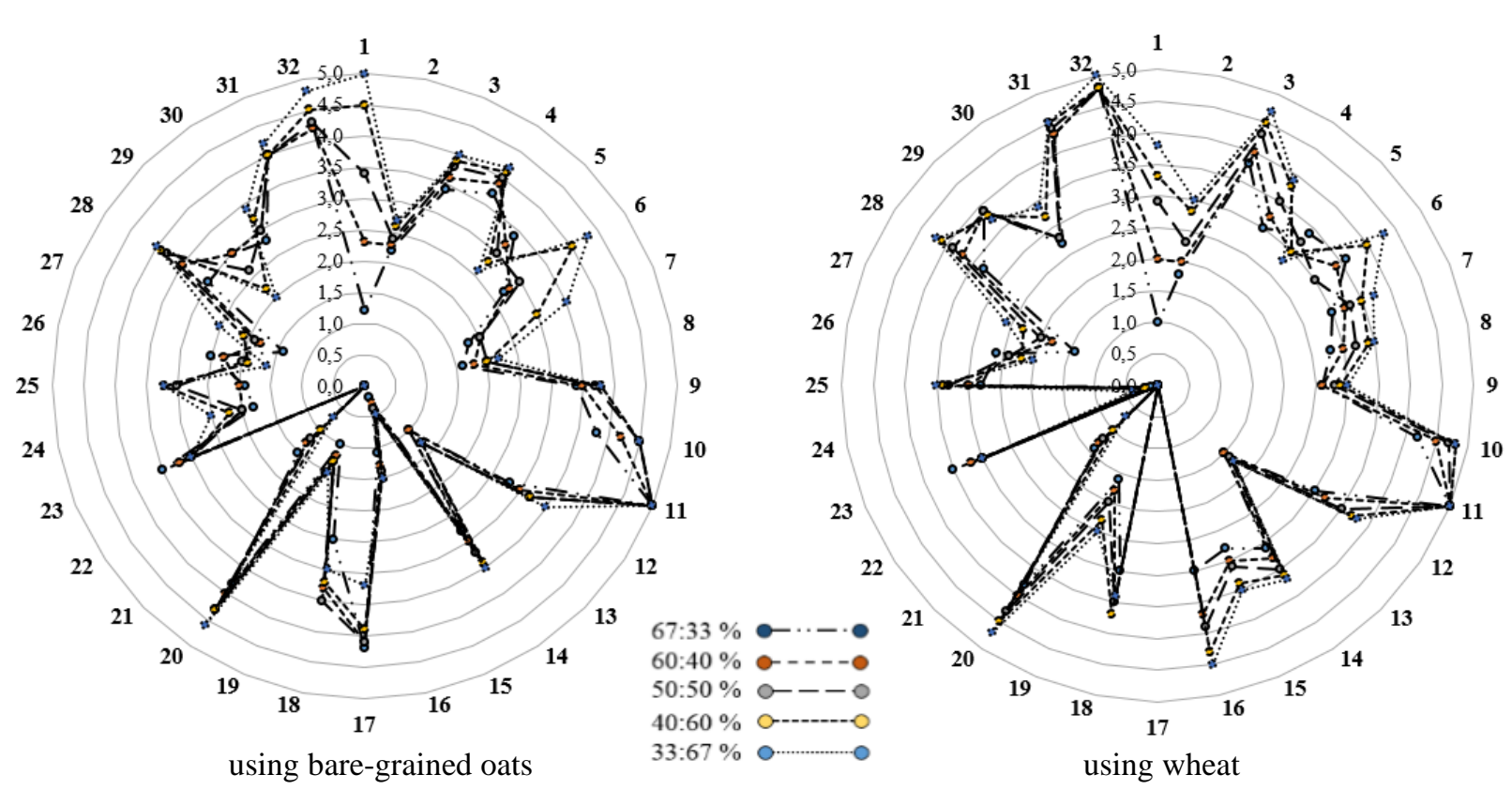

1 - uniformity of grain coating with extract, 2 - clarity of extract, 3 - color saturation, 4 - brown color,

5 - golden color, 6 - glossy cast, 7 - brown color of grain, 8 - golden color of grain, 9 - pallor of grain,

10 - uniformity of grain coloring, 11 - grain integrity; 12 - aroma intensity, 13 - bread aroma, 14 - malt aroma,

15 - caramel aroma, 16 - honey aroma, 17 - apple (herbal) aroma; 18 - harmony of tastes, 19 - saturation of taste,

20 - sweetness, 21 - sourness, 22 - bitterness, 23 - apple (herbal) taste, 24 - honey taste, 25 - malt taste,

26 - herbaceous of grain, 27 - sweetness of grain; 28 - extract viscosity, 29 - softness of grain shell,

30 - hardness of grain endosperm; 31 - relevance, 32 - naturalness

Figure 4. The general portrait of preserved product depending on the proportion of sprouted grain in preserved product

Comparing the portraits, it is noted that when the proportion of sprouted grain in the preserved product increases, the grain coating with extract, pallor and hardness of the grain, the clarity of the extract, glossy casting, brown intensity and the severity of malt-apple aroma decreases. It was found that the most saturated brown color with a glossy cast, sweet apple-honey taste with light sourness, prominent apple-honey-malt aroma, high relevance and naturalness the samples were characterized in ratios of 33: $67 \%$ and $40: 60 \%$, the harmony of sweet-sourness taste in the product was observed at ratios of 60: $40 \%$ and 50:50\%. It should be noted that in the ratio of 40: $60 \%$ and 50: $50 \%$, the extract completely covers the grain, which promotes uniform saturation of the grain with the extract and better preservation of the product.

After studying the model samples of the preserved product, a conversation was held about the weaknesses and strengths of the organoleptic characteristics of the product. Sensory SWOT analysis showed that essential for potential consumers is mainly a pleasant apple (using sprouted bare-grained oats) and honey (using sprouted wheat) aroma, a sweet taste with light sourness, golden brown color, significant functionality and usefulness of the product; weakness - unpleasant aftertaste, non-harmonic sweet or sour taste with bitterness, turbidity of the product.

In the next step, the testers noted the most preferred intensity of the descriptor in the analyzed products. The received averaged scores were multiplied by the significance factor and converted to a 5-point scale. Based on the results of focus group preferences, a general portrait of the "ideal" preserved product was developed, presented in Fig. 5. 


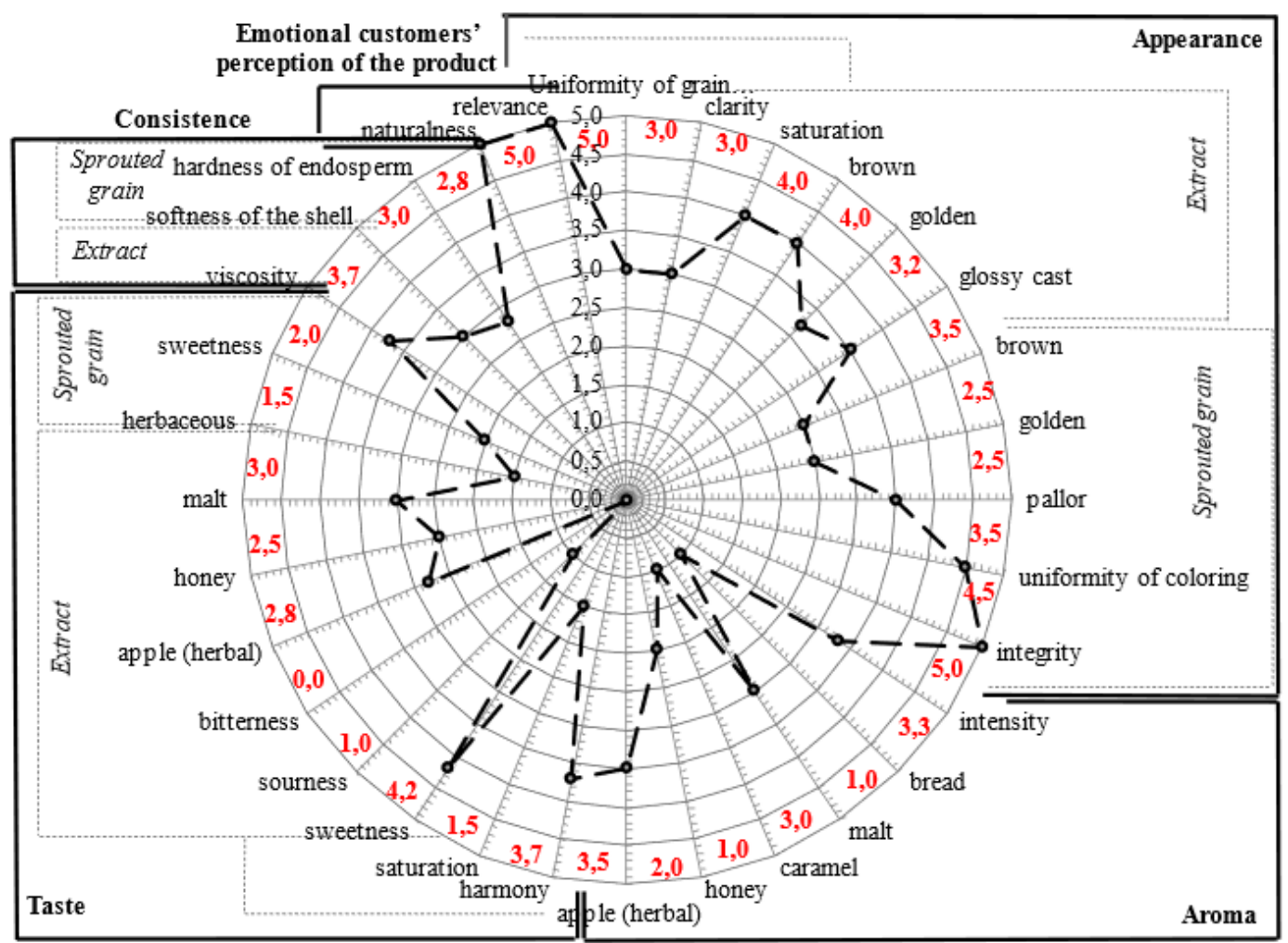

Figure 5. General portrait of «ideal» preserved product

As can be seen from the results presented in the Fig. 5 , the "ideal" portrait of the preserved product was characterized as clarity with light opalescence, with strong brown saturation, moderate golden intensity with a glossy cast, with strong viscosity, uniformly colored whole grain, with strong apple severity and moderate malt aroma intensity, harmony of sweet taste with light sourness, moderate saturation of apple-malt taste, with a weak intensity of sweetherbal taste of the grain, moderate hardness of the grain, lack of bitterness. Comparison of variations of the preserved product model samples relative to the "ideal" portrait made it possible to recommend the following ratio of ingredients in the preserved product: using sprouted bare-grained oats -50 : $50 \%$, using sprouted wheat $-40: 60 \%$.

\section{Conclusions}

As a result, a panel of descriptors is formed, taking into account the organoleptic indicators and emotional customers' perception of the preserved product using sprouted grain and malt extract. Characteristic was given to descriptors and significance coefficients of each feature were determined. A comparative evaluation of the preserved product was carried out depending on the proportion of sprouted grain and malt extract. An "ideal" portrait of the preserved product has been developed taking into account the strengths and weaknesses of the product, which allows to model the consumer characteristics of the product and correct undesirable shades and flavors at the stage of development of new products. The following ratios of ingredients are recommended for production of preserved product: $40 \%-50 \%$ of sprouted grain and $50 \%-60 \%$ of extract. Quality indicators of the product are characterized by high consumer preferences. 


\section{Acknowledgements}

The studies described in this article were carried out as part of a student grant on task no. 20200555 together with the Ministry of Education of the Republic of Belarus.

\section{References}

Berezhnaya O., Dubtsov G., Voyno L. Wheat germ - a food ingredient. Journal of Food Industry, 2015, 5: 26-29. [In Russian] https://cyberleninka.ru/article/n/prorostkipshenitsy-ingredient-dlya-produktovpitaniya/viewer

Bolotko A.Yu., Mikulinich M.L. Sensory analysis and public catering quality control: Lecture notes. Mogilev: MSUF Publ., 2015, 116 pages. Print ISBN: 978-985-6985-27-3. [In Russian] https://elibrary.ru/item.asp?id=28813739

Burmagina T., Gnezdilova A. Use of malt extract to replace sucrose in the production of concentrated dairy products. Current Issues in Engineering Sciences in Modern Conditions. Collection of Research Papers on the Results of the International Scientific and Practical Conference. St. Petersburg, 2015, pp. 181-184. [In Russian] https://elibrary.ru/item.asp?id=23198255

Chugunova O., Zavorokhina N. Use of tasting analysis methods in modeling food formulations with given consumer properties. Publishing House of Ural State University of Economics, Yekaterinburg, 2010, 148 pages. Print ISBN 978-5-9656-0153-0. [In Russian] https://elibrary.ru/item.asp?id=19619444

Domaretsky V. Technology of extracts, concentrates and drinks from vegetable raw materials (Training manual). Moscow, FORUM. 2007, 444 pages. Print ISBN: 978-591134-120-6. [In Russian] https://znanium.com/catalog/document?id=644 $\underline{46}$

Druker O.V., Kruchkova V.V., Kontareva V.Yu., Skripin P.V., Gorlov I.F. Application description profile method in the development of enriched dairy products. Journal of Agro-

Food Innovations. 2018, 2(2): 68-73. [In

Russian] https://doi.org/10.31208/2618-73532018-1-2-68-73

Evdokhova L.N., Masansky S.L. Commodity examination. Minsk: High School Publ., 2013,
336 pages. Print ISBN: 978-985-06-2165-8. [In Russian] https://1lib.eu/book/2905674/169ae2?regionCh anged $=\&$ redirect $=365441$

ISO 13299-2015. Sensory analysis - Methodology. General guide of sensory profiling. Moscow: International Organization for Standardization (ISO), 2016. [In Russian] https://internetlaw.ru/gosts/gost/63296/

ISO 8586-2015. Organoleptic analysis - The general guidelines on selection, training and control of work of the selected testers and experts-testers. Moscow: International Organization for Standardization (ISO), 2017. [In Russian] https://standartgost.ru/g/ГОCТ_ISO 8586-2015

ISO 8587-2015. Sensory analysis - Methodology. Ranging. Moscow: International Organization for Standardization (ISO), 2016. [In Russian] https://standartgost.ru/g/ГOCT ISO 8587-2015

Mikulinich M., Azarenok N., Bolotova P., Guzikova N. Evaluation of nutritional and biological value of polymalt extracts from malts of grain raw materials of the Belarusian selection. Materials of the II International Congress «Science, Nutrition and Health»; 2019 October 3-4, Minsk, BY. ICC of the Ministry of Finance of the Republic of Belarus, Minsk, 2019, pp. 540-547. Print ISBN 978-9857224-76-0. [In Russian] https://www.elibrary.ru/item.asp?id=41827596

Moiseeva N.S., Motovilov O.K. Application of the descriptor and profile method in development of the smoked baked product from meat of turkey. Conference "Science, Nutrition and Health". Materials of the II International Congress. Minsk, 03-04 October 2019, ITC of the Ministry of Finance, Barnaul, Vol. 2, pp. 64-66. [In Russian] http://www.spsl.nsc.ru/FullText/konfe/XVIpek2 0192.pdf

Pike P., Abdel-Aal E., McElroy A. Antioxidant activity of oat malt extracts in accelerated corn oil oxidation. Journal of the American Oil Chemists' Society. 2007, 84(7): 663-667. https://doi.org/10.1007/s11746-007-1088-7

Pochitskaja I., Lobazova I., Seliazniova A. The preferences of the people leading active lifestyle as the basis for creation of national functional products. Food Industry: Science and Technology. 2017, 2(36): 41-46. [In Russian] 
http://www.new.belproduct.com/assets/files/Pis hhevaya-promyshlennost-2-36-2017.pdf

Prasol I., Golembovskaya N., Slobodyanyuk N., Ochkolyas E. Sensory analysis of semi-finished minced fish products by the flavor profile method. Scientific Bulletin of LNUVMB named after SZ Gzhytskoho, 2017, 19(80): 83-87. [In Russian] https://docplayer.net/72943383Sensorniy-analiz-ribnih-sichenihnapivfabrikativ-metodom-profilyufleyvoru.html

Safronova T., Panchishina E., Maksimova S., Surovtseva E., Slutskaya T., Chupikova E. Resolution power of the organoleptic profile method in the research and food quality control. News of Higher Educational Institutions. Food Technology. 2017, 5-6: 103-108. [In Russian] https://ivpt.kubstu.ru/tocs/359-360/22

Samchenko O., Merkucheva M. Germinated seed perspective raw material to develop new types of products. A New University. Series:

Technical Sciences. 2015, 7-8(41-42): 27-32. [In Russian] https://www.elibrary.ru/contents.asp?id=34115 $\underline{088}$

STB ISO 11036-2007. Organoleptic analysis Methodology. Texture profile. Minsk: BelSISC Publ., 2007. [In Russian] https://standartgost.ru/g/СТБ_ИСО_110362007

STB ISO 6564-2007. Organoleptic analysis Methodology. Flavour profile methods. Minsk: BelSISC Publ., 2007. [In Russian] https://files.stroyinf.ru/Data2/1/4293740/42937 40453.pdf

Stone H., Sidel J. Sensory Evaluation Practices (third edition). Food Science and Technology. Elsevier Academic Press (USA). 2004, 378 pages, ISBN 0-12-672690-6. [In Russian] http://en.bookfi.net/book/1254191

Stone, H. Sensory Evaluation: Science and Mythology. Wine Research. 2005, 8: 47-56.

Zabalueva Y., Bazhenova B., Meleshkina N. Effect of the plant extract on the formation of main sensory characteristics of dry sausages. Food Industry: Science and Technology. 2017, 1(35): 58-63. [In Russian] http://www.new.belproduct.com/assets/files/Pis hhevaya-promyshlennost-1-35-2017.pdf

Zavorohina N.V. Development and application of methodology of modeling of soft drinks taking into account touch preferences of consumers torus. DSc Thesys. Kemerovo Technological Institute of the Food Industry, 2014. [in Russian] https://www.dissercat.com/content/razr abotka-i-primenenie-metodologiimodelirovaniya-bezalkogolnykh-napitkov-suchetom-sensorn/read

Zavorokhina N., Chugunova O. Potential of the descriptive and profile method of degustation analysis. Bulletin of the South Ural State University Series "Food and Biotechnology". 2014, 2(2): 58-63. [In Russian] https://vestnik.susu.ru/food/article/view/2540/2 444

Znamenskaya T. Polisol is an extract from sprouted cereal grains. Health and Longevity. Natural Medicine. 2009, 48(1): 2. [In Ukrainian] 